\title{
Effect of diatom nutrient limitation on copepod development: role of essential lipids
}

\author{
W. C. M. Klein Breteler*, N. Schogt, S. Rampen \\ Royal Netherlands Institute for Sea Research (NIOZ), PO Box 59, 1790 AB Den Burg, The Netherlands
}

\begin{abstract}
The development of 2 copepod species was studied with nutrient-limited algae as the sole food source. Thalassiosira weissflogii was grown under different levels of nitrogen and phosphorus limitation. Young copepodite stages of Temora longicornis (Müller) and Pseudocalanus elongatus (Boeck) developed at significantly reduced rates, both when fed with the nitrogen- and the phosphorus-limited diatom. At high levels of nutrient limitation, the copepods often did not reach maturity. The lipid composition of the diatom was strongly affected by nutrient limitation. Both the proportion and the content of long-chain polyunsaturated fatty acids (PUFAs) were reduced, particularly under phosphorus limitation. The dominant sterol, $\Delta^{5,24(28)} \mathrm{C} 28: 2$, was reduced by about a factor of 2 both under nitrogen and phosphorus limitation. The results suggest that the different growth rates of the copepods observed can be explained by the different lipid composition of the algae due to nutrient limitation.
\end{abstract}

KEY WORDS: Copepods $\cdot$ Development $\cdot$ Food quality $\cdot$ Diatoms $\cdot$ Fatty acids $\cdot$ Polyunsaturated fatty acids $\cdot$ PUFAs $\cdot$ Sterols

\section{INTRODUCTION}

Among nutrients, inorganic nitrogen, phosphorus and silicate determine the production of phytoplankton serving as food for higher trophic levels. Shifts in inorganic nutrient ratios affect the species composition of phytoplankton (Brett et al. 1999). Due to their variable size and morphology, different species of algae influence the grazing success and, hence, the growth rate and reproduction of copepods (van Nieuwerburgh et al. 2004). In addition, the biochemical composition of algae not only differs among species (Sargent et al. 1987), but is also dependent on the ambient concentration of nutrients (e.g. Shiffrin \& Chisholm 1981, Reitan et al. 1994), which may determine the quality of algae as a food source for zooplankton.

The effect of the algal biochemistry on secondary producers has received considerable attention, but major questions still remain to be answered. Growth and/or egg production of zooplankton were shown to be correlated with the bulk protein content of algal food (Roman 1991, Kleppel \& Hazzard 2000) and with the lipid composition of seston (Jonasdottir et al. 1995, Müller-Navarra 1995, Pond et al. 1996, Hazzard \& Kleppel 2003). Many studies focused on the elemental composition of zooplankton as affected by inorganic nutrient limitation of the algal food (Sterner \& Schulz 1998). However, stoichiometric models of carbon and nitrogen do not explain differences in growth rate of marine copepods (Anderson \& Hessen 1995). In addition to the incorporation of inorganic nutrients, algae produce several organic micronutrients, which are essential for zooplankters and cannot be synthesised by them, potentially overruling the bulk effects of carbon or nitrogen limitation (Anderson \& Pond 2000). Among these micronutrients, specific amino acids in the food of copepods appear to be essential for their egg production (Kleppel \& Burkart 1995, Guisande et al. 2002). The present study focuses on the development of juvenile copepods as influenced by N- and Plimitation of their algal food, and on a possible interaction with the essential lipid composition of the food.

In general, production of lipids by algae depends on their growth conditions. In various species of algae, the 
composition of sterols is strongly dependent on the temperature and the spectral quality of the light source, and is usually related to the growth stage of the algae (Veron et al. 1996, Volkman 2003 and references therein). The total sterol content of algae is related to the important role of these compounds in biological membranes such as the chloroplast membranes (Wood 1988). In fatty acids, the proportion of unsaturated fatty acids and, in particular, of long-chain polyunsaturated fatty acids (PUFAs), generally increases with nutrient and light conditions that promote algal growth (e.g. Thompson et al. 1992, Otero et al. 1997). An altered composition of fatty acids connected with algal growth rates is due to shifts among chloroplast-related phospholipid classes (Mock \& Kroon 2002) or glycolipids (Sargent et al. 1987) and to storage of saturated/neutral lipids. Although PUFA synthesis seems tightly linked to the algal growth rate, the total content of these fatty acids in algae does not necessarily change (Reitan et al. 1997 and references therein) or may even increase during the stationary growth phase (Brown et al. 1996).

Sterols are lipids that arthropods cannot make at all (Goad 1981). The long-chain PUFAs eicosapentaenoic acid (EPA) and docosahexaenoic acid (DHA) cannot be made at sufficient rates by most animals (Brett \& Müller-Navarra 1997). Deficiencies of these lipids in the food source were shown to affect the growth rate of Daphnia spp. (Ravet et al. 2003, von Elert et al. 2003) and copepods (Klein Breteler et al. 1999, 2004). Studies showing a connection between the growth conditions of algae and their lipid composition as well as an effect on the growth of zooplankton are equivocal. Positive correlations have been found for egg production of Acartia tonsa (Jonasdottir \& Kiørboe 1996) and for the growth of oyster and prawn larvae (Enright et al. 1986, D'Souza \& Kelly 2000). Negative correlations have been observed for growth of mussel larvae (Leonardos \& Lucas 2000). Weers \& Gulati (1997) found that P- and N-limitation affected the PUFA content of the algae similarly, but only under P-limitation was a lower PUFA content correlated with a reduced growth rate of Daphnia galeata. These contrasting observations suggest that, in addition to fatty acids, other unknown biochemical compounds may control the growth rate of zooplankton.

The objective of the present study was to determine the effect of nutrient limitation of food algae on the rate of development of copepods, and to find a possible explanation based on the lipid composition of the food. Thus far, the effect of nutrient concentrations on the sterol content of the food algae has not been considered in growth studies of zooplankton. We hypothesise that $\mathrm{N}$ - and P-limitation reduce the production of sterols and/or unsaturated fatty acids of algae, and that reduction of essential lipids reduces the growth rate of copepods. To test this hypothesis, Thalassiosira weissflogii was cultured under different levels of N- and Plimitation and used as food source for 2 species of copepod larvae. The development rate of the copepods was measured. The fatty acid and sterol content of the algae was checked at high levels of $\mathrm{N}$ - and P-limitation as compared to nutrient-replete conditions.

\section{MATERIALS AND METHODS}

Using unialgal, continuous cultures, the diatom Thalassiosira weissflogii (CCMP strain 1049) was grown at different levels of nutrient limitation and fed to young stages of the copepods Temora longicornis (Müller) and Pseudocalanus elongatus (Boeck). Development and mortality rates of the copepods were monitored. The cryptophyte Rhodomonas sp. was used as a goodquality control food, to check for any differences among experiments.

Cultures. Copepods were obtained from brood stocks of Temora longicornis and Pseudocalanus elongatus, which were continuously cultured in the laboratory at $15^{\circ} \mathrm{C}$ with a surplus of food (>300 $\mu \mathrm{g} \mathrm{C} \mathrm{l}^{-1}$ ). The food consisted of Rhodomonas sp., the haptophyte Isochrysis galbana and the heterotrophic dinoflagellate Oxyrrhis marina. Details of the culture conditions are described by Klein Breteler \& Gonzalez (1986, 1988).

Rhodomonas sp. was cultured in a 31 chemostat, using a dilution rate of $0.16 \mathrm{~d}^{-1}$ of $\mathrm{f} / 2$ medium (Guillard 1975), a constant air supply, a light intensity of ca. $150 \mu \mathrm{E} \mathrm{m}^{-2} \mathrm{~s}^{-1}$, a 16:8 h light:dark regime and the temperature held at $15^{\circ} \mathrm{C}$. Thalassiosira weissflogii was grown in similar continuous cultures of 1 to 31 , but under $\mathrm{N}$ - or P-limitation as well as under nutrientreplete conditions. Nutrient-limited media were prepared from natural seawater with a very low nutrient content ( $\mathrm{N}$ and $\mathrm{P}$ concentration $<0.3 \%$ of that of $\mathrm{f} / 2$ medium). To obtain different levels of limitation, at certain time intervals, the rate of dilution of the culture or the concentration of the limiting element of the medium was changed (Kiørboe 1989). After the experiments with nutrient-limited algae, full strength $\mathrm{f} / 2$ medium, containing $883 \mu \mathrm{M} \mathrm{NO}_{3}{ }^{-1}$ and $36 \mu \mathrm{M} \mathrm{PO}_{4}{ }^{-3}$, was applied to the previously P-limited culture, to obtain a culture that was not limited by nutrients. The different conditions are shown in Table 1. It should be noted that the differences between the limitation levels are relative and for $\mathrm{N}$ and $\mathrm{P}$, not necessarily the same. The cultures were maintained from September 1998 until March 2002, enabling replicate copepod experiments with the different qualities of food.

Concentrations and cell volumes of the algae were measured in samples from the continuous cultures using an Elzone electronic particle counter (Particle 
Table 1. Thalassiosira weissflogii. Conditions of continuous cultures, dilution rates $\left(\mathrm{d}^{-1}\right)$, volume-specific cell $\mathrm{C}$ - and $\mathrm{N}$ content ( $\mathrm{fg}_{\mathrm{m}} \mathrm{m}^{-3}$ ) and $\mathrm{C}: \mathrm{N}$ ratios under $\mathrm{N}$ - and P-limitation. Full strength $\mathrm{f} / 2$ medium was used, except for the concentration of the limiting element indicated; dilutions of $\mathrm{N}$ and $\mathrm{P}$ were not the same, since the P-limited culture was washedout in $\mathrm{f} / 20$ medium. The nutrient-replete culture is represented by the 'P-limited' culture at level 0 (1 observation). Cand $\mathrm{N}$-values shown indicate replicate samples $(\mathrm{n}=2)$ collected at the same time

\begin{tabular}{|lccccccc|}
\hline \multicolumn{3}{l}{$\begin{array}{l}\text { Limitation } \mathrm{d}^{-1} \\
\text { level }\end{array}$} & Medium & \multicolumn{5}{c}{ Cell content } & Avg. \\
& & & \multicolumn{2}{c}{$\mathrm{C}$} & $\mathrm{N}$ & $\mathrm{C}: \mathrm{N}$ \\
\hline \multicolumn{2}{l}{ N-limited } \\
0 & & & & & & & \\
1 & 0.30 & - & - & - & - & - & - \\
2 & 0.30 & $\mathrm{f} / 10$ & 161 & 177 & 16 & 17 & 10.1 \\
3 & 0.30 & $\mathrm{f} / 20$ & 183 & 187 & 18 & 16 & 10.9 \\
4 & 0.18 & $\mathrm{f} / 20$ & 201 & 207 & 10 & 10 & 20.4 \\
P-limited & 0.10 & $\mathrm{f} / 20$ & 278 & 265 & 37 & 37 & 7.4 \\
0 & 0.30 & $\mathrm{f} / 2$ & 251 & - & 38 & - & 6.7 \\
1 & 0.30 & $\mathrm{f} / 5$ & 206 & 253 & 29 & 35 & 7.2 \\
2 & 0.30 & $\mathrm{f} / 10$ & 261 & 246 & 28 & 28 & 9.0 \\
3 & 0.18 & $\mathrm{f} / 10$ & 207 & 251 & 18 & 23 & 11.0 \\
4 & 0.10 & $\mathrm{f} / 10$ & 294 & 270 & 22 & 19 & 13.7 \\
\hline
\end{tabular}

Data). For determination of the carbon and lipid content, samples were collected at the time when the experiments were performed. The samples were filtered onto combusted Whatman GF/F filters. All samples were stored at $-50^{\circ} \mathrm{C}$; those for lipid analysis, also under $\mathrm{N}_{2}$. The carbon and nitrogen content was measured using a Carlo Elba CHN analyser.

Lipid analysis. For lipid analyses, samples were saponified and extracted using $\mathrm{KOH} /$ methanol as described by Klein Breteler et al. (2004). Extracted lipids were analysed by gas chromatography and gas chromatography-mass spectrometry as described by Klein Breteler et al. (1999), except for an injection of samples at $70^{\circ} \mathrm{C}$ and in both analyses, a similar oven programming of $20^{\circ} \mathrm{C} \mathrm{min} \mathrm{m}^{-1}$ between 130 and $320^{\circ} \mathrm{C}$, which was held isothermally for $20 \mathrm{~min}$ thereafter. Fatty acids and sterols were identified from the retention times and the mass spectra of the extracted compounds. Double-bond positions of fatty acids were determined by comparing retention times with those of PUFA No. 1 and 2 standard mixtures (Matreya). For sterols, no standards were used.

Experimental set-up. The development times of the copepods were measured using an experimental setup with $1.2 \mathrm{l}$ glass bottles, which were rotated at $1 \mathrm{rpm}$ using a rolling-table in a temperature-controlled room held at $15^{\circ} \mathrm{C}$ under dim light conditions. Replicate experiments ( 2 to 4 ) were done, performed one after the other. Larvae and young copepodites (552 \pm 220 $[$ mean \pm SD] and $381 \pm 99$ specimens of Temora longicornis and Pseudocalanus elongatus, respectively) were taken from the brood stock, rinsed with doublefiltered $(2 \mu \mathrm{m})$ seawater and incubated in $2 \mu \mathrm{m}$-filtered seawater with food. The new cohorts usually comprised 4 larval stages, ranging from nauplius III to copepodite II among the different experiments. Incubation continued until most animals were mature, collected for sampling or dead. Food was supplied from the continuous cultures of Rhodomonas sp. or Thalassiosira weissflogii at a concentration of $\geq 300 \mu \mathrm{g} \mathrm{Cl}^{-1}$. Carbon estimates of these food suspensions were based on cell counts and cell volumes, using volumecarbon conversions established for T. weissflogii and Rhodomonas sp. To test for toxicity of $T$. weissflogii, in one experiment, a mixture of the 2 algae species was used, each at half the concentration of the single food experiments. Every 1 to 2 d, $90 \%$ of the food medium was removed, using reverse flow filtration through a $50 \mu \mathrm{m}$ mesh, and replaced by new medium with food. The food concentration was measured using the Elzone particle counter twice per week.

Sampling of copepods started at least $1 \mathrm{~d}$ after the beginning of the incubation, to allow for adaptation to the new food source. The sampling was performed 3 times per week to determine the stage distribution and mortality. At the same time, the copepod density was diluted to keep the copepod biomass below a value equivalent to about 40 adult animals ${ }^{-1}$. Usually, 30 to 50 copepods were collected per sampling. Stage duration was calculated from the Median Development Time of successive stages as described by Klein Breteler et al. (1994). Instantaneous rates of mortality were calculated, including a correction for sampling mortality according to Klein Breteler et al. (2004).

ANOVA was used to test for differences of stage duration and mortality among the different levels of nutrient limitation. We used the general linear model (SYSTAT 10.0), with duration or mortality as dependent variables, and algal species and nutrient limitation as independent, categorical variables.

\section{RESULTS}

\section{Development}

Nutrient-replete Thalassiosira weissflogii enabled the copepodites to develop to maturity at a high rate, almost as fast as with the control food alga Rhodomonas sp. (Figs. 1 \& 2, Lim 0). This indicates that the diatom was a good-quality food source, to which the young copepods easily adapted after their previous feeding on flagellates in the stock culture.

When feeding on nutrient-limited Thalassiosira weissflogii, in both copepod species, the rates of development decreased in comparison to the nutrient- 

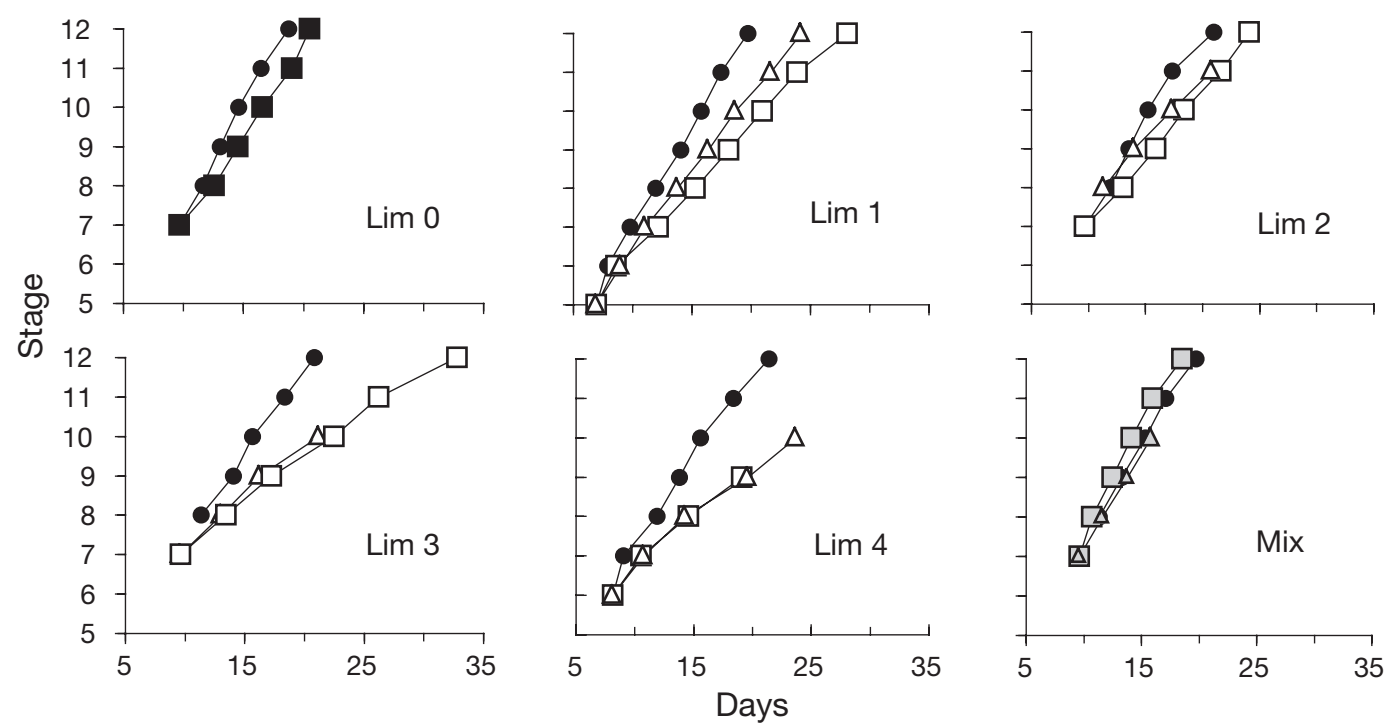

Fig. 1. Temora longicornis. Cumulative mean stage duration (d) of nauplii (stages 5 to 6) and copepodites (stages 7 to 12 ) using Thalassiosira weissflogii as food, which was cultured under nutrient-replete conditions (Lim 0, 口) or limited by nitrogen (Lim 1 to $4, \Delta$ ) or phosphorus $(\square)$ at limitation levels increasing from 1 to 4 . Control experiments with Rhodomonas sp. (•). Experiment with mixture of Rhodomonas sp. and T. weissflogii (Mix) at limitation level 3 of nitrogen $(\Delta)$ or phosphorus ( $\square$ ). The mixed culture bottle of $T$. longicornis at N-limitation was lost by accident at Day 16 . The cumulative data shown include the duration of the missing young stages as observed at $15^{\circ} \mathrm{C}$ and optimal food conditions (Klein Breteler et al. 1994)
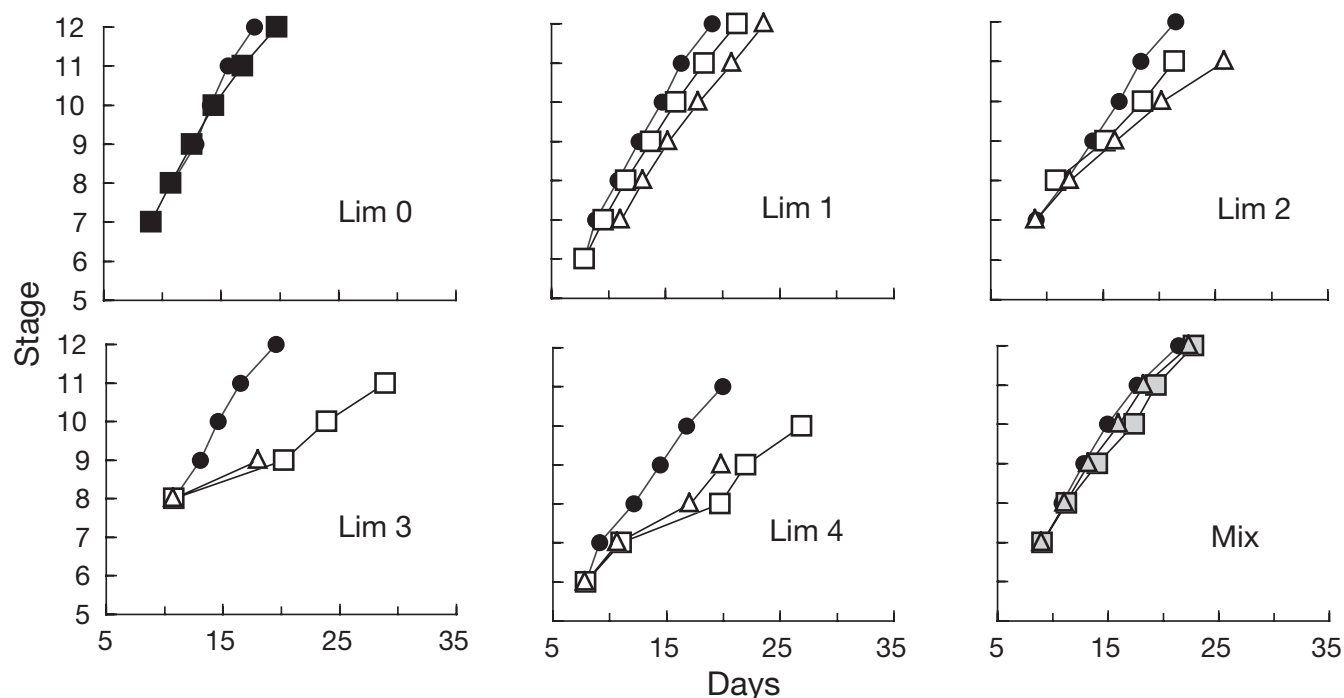

Fig. 2. Pseudocalanus elongatus. Cumulative mean stage duration (d) of nauplii (stages 5 to 6) and copepodites (stages 7 to 12) using Thalassiosira weissflogii as food, which was cultured under nutrient-replete conditions (Lim 0 , $\square$ ) or limited by nitrogen (Lim 1 to $4, \Delta$ ) or phosphorus $(\square)$ at limitation levels increasing from 1 to 4 . Control experiments with Rhodomonas sp. (•). Experiment with mixture of Rhodomonas sp. and T. weissflogii (Mix) at limitation level 3 of nitrogen ( $\Delta$ ) or phosphorus ( $\square$ ). The cumulative data shown include the duration of the missing young stages as observed at $15^{\circ} \mathrm{C}$ and optimal food conditions (Klein Breteler et al. 1994)

replete diatom. At increasing levels of limitation, the development slowed down in comparison with the control food (Figs. 1 \& 2). At high levels of nutrient limitation, development often ceased and, hence, the duration of older stages could not always be determined. For statistical testing, therefore, the data of copepodite stages II and III were selected, which were more or less complete in all experiments. Using the mean duration (after ln-transformation) of these 2 stages, the overall effect of limitation was always significant (ANOVA, Table 2, p < 0.01). In 3 out of 4 cases, a significant interaction $(p<0.05)$ between limi- 
Table 2. Temora longicornis and Pseudocalanus elongatus. Results of ANOVA, showing the effect of nutrient limitation (Lim) and algal species (Alga) on the mean duration of copepodite stages II and III. N-lim: nitrogen limitation; P-lim: phosphorus limitation; df: degrees of freedom; SS: sum of squares. Significance, including total treatment and interaction term $(\operatorname{Lim} \times$ alga $),{ }^{*} \mathrm{p}<0.05,{ }^{* *} \mathrm{p}<0.01$ and ${ }^{* * *} \mathrm{p}<0.001$

\begin{tabular}{|c|c|c|c|c|}
\hline & \multicolumn{2}{|c|}{ N-lim } & \multicolumn{2}{|c|}{ P-lim } \\
\hline & & SS & $\mathrm{df}$ & SS \\
\hline \multicolumn{5}{|c|}{ Temora longicornis } \\
\hline Treatment & 9 & $3.340^{* * *}$ & 9 & $3.314^{* * *}$ \\
\hline Alga & 1 & $1.945^{* * *}$ & 1 & $2.009^{* * *}$ \\
\hline Lim & 4 & $0.961^{* *}$ & 4 & $1.112^{* * *}$ \\
\hline Lim $\times$ Alga & 4 & 0.299 & 4 & $0.590^{*}$ \\
\hline Error & 20 & 1.163 & 19 & 0.716 \\
\hline \multicolumn{5}{|c|}{ Pseudocalanus elongatus } \\
\hline Treatment & 9 & $3.550^{* * *}$ & 9 & $4.463^{* * *}$ \\
\hline Alga & 1 & $1.224^{* * *}$ & 1 & $1.177^{* * *}$ \\
\hline Lim & 4 & $1.557^{* *}$ & 4 & $1.518^{* * *}$ \\
\hline Lim $\times$ Alga & 4 & $1.036^{*}$ & 4 & $1.103^{* * *}$ \\
\hline Error & 14 & 0.871 & 15 & 0.315 \\
\hline
\end{tabular}

tation level and algal species was detected, indicating the similar duration at limitation level 0 ; however, a generally increasing difference between the control food and the higher levels of limitation was detected (Fig. 3). An exception to this seems to be the relatively short stage duration of Pseudocalanus elongatus at limitation level 4. However, this low value was probably biased due to the limited data available for testing. If the very slow development of copepodite stage I (cf. Fig. 2, Lim 4, stage 7) could have been included in the test, the average stage duration of $P$. elongatus at limitation level 4 would have been much higher.

To test for possible toxicity of nutrient-limited Thalassiosira weissflogii, we used this diatom limited by $\mathrm{N}$ or P (both at limitation level 3) and mixed it with Rhodomonas sp. to feed the copepods. In comparison to the control food alone, no difference in the rate of development was detected (Figs. 1 \& 2, Mix), which indicates that the diatom was not toxic due to nutrient limitation.

\section{Mortality}

The copepod mortality was calculated in individual cultures using the linear relation between the natural logarithm of copepod abundance versus time. The regression coefficient was not significantly affected due to nutrient limitation by $\mathrm{N}$ or $\mathrm{P}$, nor was there a significant interaction with the algal species (ANOVA, $\mathrm{p}>0.05$ ). However, it should be noted that the death rates due to sampling were high, which caused the experiments to be terminated too early to observe the mor-

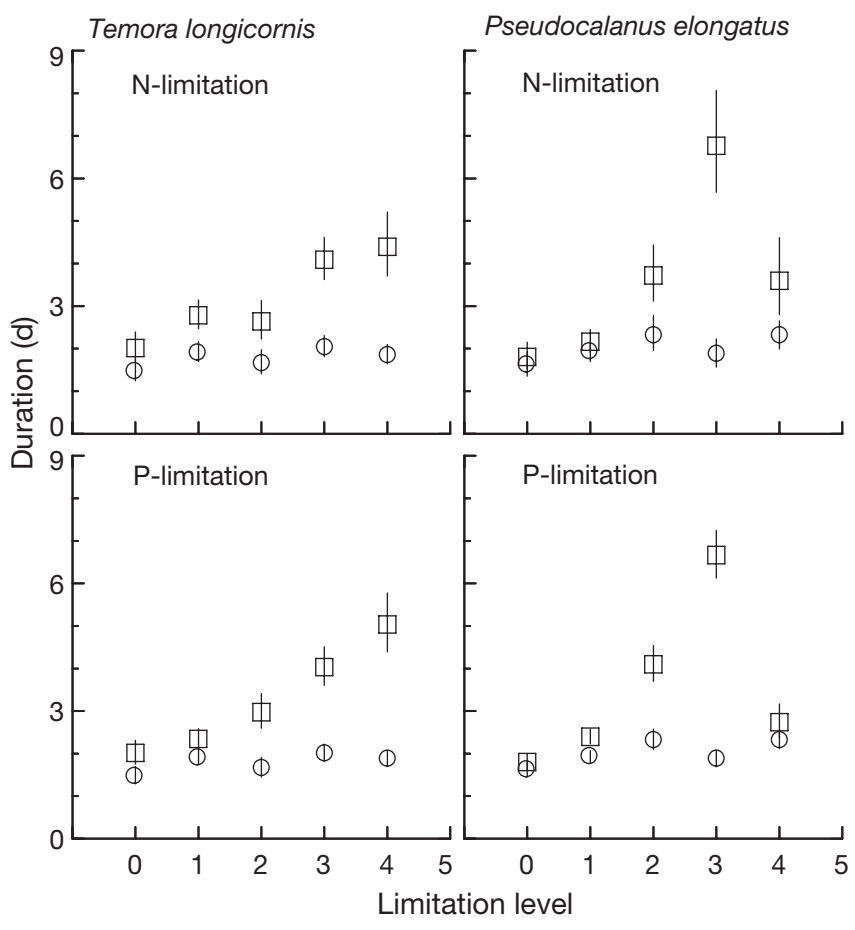

Fig. 3. Temora longicornis and Pseudocalanus elongatus. Mean duration of copepodite stages II and III at different levels of nitrogen or phosphorus limitation $(\square)$. Limitation level 0 represents nutrient-replete conditions. Control experiments with Rhodomonas sp. (O). Symbols and bars indicate (back-transformed) means $\pm \mathrm{SE}$, using the error mean square (Table 2) as an estimate of the residual variance on the logarithmic scale

tality in cultures with stagnant copepod development, mainly at high levels of nutrient limitation (Figs. 1 \& 2).

\section{Lipids}

For lipid analyses, samples were selected from cultures that differed most in nutrient conditions, but taking into consideration the measured $\mathrm{C}: \mathrm{N}$ ratio (Table 1). The C:N ratio of the samples increased at increasing level of nutrient limitation, except for the, unexplained, low $\mathrm{C}: \mathrm{N}$ ratio of the N-limited culture at limitation level 4. The latter sample, therefore, was neglected and the sample of limitation level 3 of the Nlimited culture was analysed together with the one of level 4 of the P-limited culture, in comparison to the sample from the unlimited culture.

The lipid composition of nutrient-replete Thalassiosira weissflogii considerably differed from the composition of the nutrient-limited cultures. Generally, the nutrient-replete culture showed a lower proportion of saturated and mono-unsaturated fatty acids and a higher proportion of long-chain PUFAs (Table 3). Most

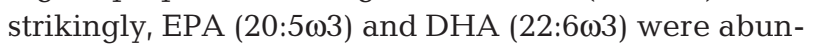


Table 3. Thalassiosira weissflogii. Distribution (\% of total) and total amount

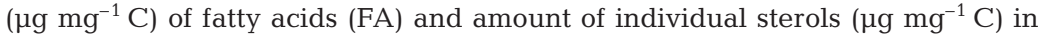
different cultures: nutrient-replete (Unlim), nitrogen-limited (N-lim) and phosphorus-limited (P-lim). Values indicate replicate samples $(\mathrm{n}=2)$ collected at the same time. nd $=$ non-detectable amount

\begin{tabular}{|c|c|c|c|c|c|c|}
\hline \multirow{3}{*}{$\begin{array}{l}\text { Fatty acid } \\
\text { C14:0 }\end{array}$} & \multirow{2}{*}{\multicolumn{2}{|c|}{ Unlim }} & \multirow{2}{*}{\multicolumn{2}{|c|}{$\begin{array}{l}\text { of total FA } \\
\text { N-lim }\end{array}$}} & \multirow{2}{*}{\multicolumn{2}{|c|}{ P-lim }} \\
\hline & & & & & & \\
\hline & 9.1 & 8.5 & 10.1 & 10.0 & 7.2 & 6.9 \\
\hline C15:0 & 1.3 & 1.2 & 1.7 & 1.7 & 1.8 & 1.5 \\
\hline C16:3 & 5.8 & 6.6 & 1.9 & 2.1 & 0.4 & 0.5 \\
\hline $\mathrm{C} 16: 1 \omega 7$ & 40.5 & 40.8 & 38.5 & 38.5 & 36.3 & 40.2 \\
\hline C16:1 & 0.6 & 0.7 & 1.8 & 1.0 & 2.5 & 1.1 \\
\hline C16:1 & 0.4 & 0.3 & 0.3 & 0.2 & nd & 0.1 \\
\hline C16:0 & 28.3 & 26.4 & 39.1 & 37.4 & 48.8 & 45.4 \\
\hline $\mathrm{C} 18: 4 \omega 3$ & 2.6 & 3.1 & 1.7 & 2.7 & 0.1 & 0.4 \\
\hline $\mathrm{C} 18: 2 \omega 6$ & 0.7 & 0.6 & 0.4 & 0.4 & 0.3 & 0.5 \\
\hline $\mathrm{C} 18: 1 \omega 9$ & 0.5 & 0.5 & 0.7 & 0.3 & 0.5 & 1.0 \\
\hline C18:1 $1 \omega 7$ & 0.2 & 0.1 & 0.5 & 0.6 & 1.7 & 1.6 \\
\hline C18:0 & 1.1 & 0.2 & 0.2 & 0.3 & 0.5 & 0.4 \\
\hline $\mathrm{C} 20: 4 \omega 6+\mathrm{C} 20: 5 \omega 3$ & 7.4 & 9.6 & 2.9 & 3.7 & nd & 0.3 \\
\hline $\mathrm{C} 22: 6 \omega 3$ & 0.9 & 1.1 & 0.0 & 0.2 & nd & nd \\
\hline C24:1 & 0.3 & 0.1 & 0.1 & 0.1 & nd & 0.1 \\
\hline $\mathrm{C} 24: 0$ & 0.1 & 0.1 & 0.0 & 0.0 & nd & 0.0 \\
\hline Unknown & 0.3 & 0.1 & nd & 0.8 & nd & nd \\
\hline $\begin{array}{l}\text { Total fatty acids } \\
\left(\mu g \mathrm{mg}^{-1} \mathrm{C}\right)\end{array}$ & 58.0 & 61.8 & 47.6 & 47.9 & 81.3 & 90.7 \\
\hline \multicolumn{7}{|l|}{ Sterols $\left(\mu g \mathrm{mg}^{-1} \mathrm{C}\right)$} \\
\hline$\Delta^{5,24(28)} \mathrm{C} 28: 2$ & 4.8 & 5.4 & 2.5 & 2.6 & 1.7 & 2.4 \\
\hline$\Delta^{5} \mathrm{C} 28: 1$ & 0.8 & 1.1 & 1.0 & 1.2 & nd & 0.7 \\
\hline$\Delta^{5,24(28) E} \mathrm{C} 29: 2$ & 0.6 & 1.0 & 0.5 & 0.6 & nd & 0.3 \\
\hline$\Delta^{5,24(28) Z} \mathrm{C} 29: 2$ & 0.1 & 0.2 & 0.1 & 0.2 & nd & 0.1 \\
\hline
\end{tabular}

sterol content of both $\mathrm{N}$ - and P-limited algae.

Thalassiosira weissflogii did not contain any $\alpha$-linolenic acid (18:3 $\omega 3)$. The absence of this fatty acid is characteristic of diatoms (Sargent et al. 1987). In contrast, $\alpha$-linolenic acid, as well as EPA and DHA, was quite abundant in Rhodomonas sp. (Klein Breteler et al. 1999). Although $\alpha$-linolenic acid is known as an essential nutrient (Brett \& Müller-Navarra 1997), the copepods developed well when feeding on nutrient-replete $T$. weissflogii. This questions whether $\alpha$-linolenic acid is an essential nutrient and supports the theory that other fatty acids play an important role in determining phytoplankton food quality. Particularly in the marine environment, where phytoplankton blooms are often dominated by diatoms, copepod egg production appears to be correlated with EPA and DHA (Jonasdottir et al. 1995, Jonasdottir \& Kiørboe 1996). The main sterol found in $T$. weissflogii was $\Delta^{5,24(28)}$ C28:2. Predominance of this sterol is characteristic of the genus Thalassiosira (Volkman \& Hallegraeff 1988). In Rhodomonas sp., mainly $\Delta^{5,22} \mathrm{C} 28: 2$ occurs (Klein Breteler et al. 1999). From

dant in the nutrient-replete $T$. weissflogii culture, whereas they hardly occurred in the nutrient-limited cultures, particularly not in the P-limited culture. Unfortunately, due to co-elution, EPA could not be dis-

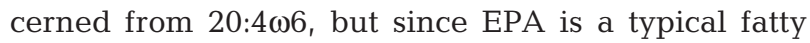
acid of diatoms (Sargent et al. 1987), the main enhancement of PUFAs in the nutrient-replete culture seems to be due to EPA. Furthermore, sterols were more abundant in the nutrient-replete culture. The difference was mainly due to $\Delta^{5,24(28)} \mathrm{C} 28: 2$, which reached only half the concentration in the nutrientlimited cultures as compared to unlimited conditions (Table 3).

\section{DISCUSSION}

Thalassiosira weissflogii appeared to be a goodquality food source for copepod development, but only when this diatom was grown under nutrient-replete conditions. Both N- and P-limitation rendered T. weissflogii inadequate for optimal copepod development. At increasing levels of nutrient limitation, the food quality further decreased, associated with a lower PUFA and the similar growth of the copepods under nutrientreplete conditions, it seems that they can convert either of these sterols to cholesterol.

The similar effect of $\mathrm{N}$ - and P-limitation on both the algal lipid composition and the copepod development suggests that the changed content of long-chain PUFAs and/or sterols of the food was the cause of the reduced development. In contrast, a reduction of the algal protein content, though probable under N-limitation, usually does not occur under P-limitation (e.g. Harrison et al. 1990). In our experiments, the specific cell nitrogen content decreased at higher levels of both $\mathrm{N}$ - and P-limitation (Table 1), but the level of the nitrogen content was quite different between $\mathrm{N}$ - and $\mathrm{P}$ limitation, which suggests that the absolute protein content of the cells did not limit the present food quality. Alternatively, it is possible that the development of the copepods was affected by a direct elemental shortage of either $\mathrm{N}$ or $\mathrm{P}$ in the respective experiments. Recently, in a model study, egg production of Acartia tonsa as observed by Kiørboe (1989) could partly be predicted from the algal C:N ratio (Kuijper et al. 2004). In this model, allowance was made for nitrogen requirement for maintenance metabolism, which seemed 
to explain the low efficiency of egg production in terms of nitrogen $\left(K_{\mathrm{N}}\right)$. However, the model did not support constancy of $K_{\mathrm{N}}$ at increasing algal C:N, as appears from the data of Kiørboe (1989) for the egg production of A. tonsa, as well as from the data of Jones et al. (2002) for the development and growth of the same species. Although the model may suggest that copepod egg production is limited by $\mathrm{N}$, from the present study, it is obvious that the $\mathrm{N}$ content co-varies with the PUFA and sterol content of the algal food, which makes it difficult to determine the real limiting factor. During Plimitation of the algal food, supplementation of $\mathrm{P}$ did not improve the growth of rotifers (Rothhaupt 1995). Recently, supplementing pure fatty acids and pure sterols showed that both long-chain PUFAs (von Elert 2002, Ravet et al. 2003) as well as sterols (von Elert et al. 2003) were limiting the growth of Daphnia spp., when feeding on cyanobacteria or on algal species which contain no or only low amounts of these essential nutrients. However, the content of sterols may constrain the development of zooplankters, even on a diet consisting of diatoms. Cholesterol supplemented to cultured diatoms can stimulate the egg production of copepods, depending on the algal and copepod species (Hassett 2004). In the latter experiments, the algae were grown in batch cultures using f/2 medium, but the growth conditions and limiting nutrient were not shown. The present experiments suggest that the apparent lack of sterols in the experiments of Hassett may be due to nutrient limitation of the algae used as food.

Essential elements other than lipids in algal food may also be affected by nutrient limitation of the algae. Egg production of copepods was shown to depend on the amino acid composition of the algal diet (Guisande et al. 2002); hence, it is possible that copepod development and growth are also limited by the content of specific amino acids in the food. Free amino acid pools of algae may rapidly change due to the availability of N (Flynn 1990, Flynn et al. 1992). However, the composition of total, hydrolysable amino acids of Thalassiosira weissflogii was about the same in nutrientreplete cultures ( $\mathrm{f} / 2$ medium, dilution rate of $0.16 \mathrm{~d}^{-1}$ ) in comparison to a N-limited culture (same medium but with a 4.5 times lower $\mathrm{N}$-content, dilution rate of $0.04 \mathrm{~d}^{-1}$ ) (W. C. M. Klein Breteler unpubl. obs.). The only exception was the absence of methionine in the $\mathrm{N}$-limited culture in comparison to an abundance of $0.5 \%$ of total amino acids in the N-replete culture. However, although methionine is an essential amino acid, it was also absent in Rhodomonas sp. which, when used as food, did not reduce copepod growth (Klein Breteler et al. 1999). The absence of an effect of culture conditions on the amino acid composition of Thalassiosira pseudonana has been reported by
Enright et al. (1986) and Brown et al. (1996). There is, therefore, little reason to assume a lack of amino acids due to nutrient limitation in the present study.

The reduced rate of copepod development when fed with nutrient-limited algae is supported by our earlier observations on Pseudocalanus elongatus using nitrogen-limited Thalassiosira weissflogii (Koski et al. 1998). In the latter paper, it is shown that the slower growth rate was not due to a different food intake, e.g. due to selection against slower-growing algae (Mullin 1963, Cowles et al. 1988). A similar food intake, independent of algal nutrient limitation, suggests that the copepods did not change their feeding behaviour to compensate for the low abundance of any limiting substances, or in response to possibly different proportions of dead cells (which may have gone unnoticed by electronic particle counting) in our cultures. In addition, Acartia tonsa showed lower development and egg production rates when feeding on nitrogen-limited T. weissflogii (Kiørboe 1989, Jones et al. 2002), not due to a different feeding behaviour of the copepods but, rather, due to the $\mathrm{N}$ content of the algae (Kiørboe 1989). The growth rate of rotifers was reduced when feeding on N-limited algae and completely ceased with P-limited algae (Rothhaupt 1995). Again, in this study, nutrient limitation of the algae had no influence on the grazing rate.

Toxic compounds from diatoms have been observed to reduce the egg hatching success of copepods due to arrested embryonic development (Miralto et al. 1999). Searching for possible toxic effects of diatoms on postembryonic development, Carotenuto et al. (2002) also observed a reduced rate or a complete halting of juvenile development in Temora stylifera, while the filled guts and high numbers of faecal pellets produced indicated that the copepods fed well on the diatoms. Although these authors stated that the diatoms in their cultures grew exponentially, they did not specify any growth rates or culture conditions to exclude possible reduced algal growth rates and, hence, growth limitation due to nutrients or light. From the present single food and mixture experiments, it appears that nutrientlimited Thalassiosira weissflogii can reduce the rate of juvenile copepod development without being toxic.

In addition to a reduced growth rate, we noticed a cessation of copepod development under strong nutrient limitation of the algal food. Such complete halting of growth does not occur under conditions of food shortage (Klein Breteler \& Gonzalez 1986, Klein Breteler et al. 1995). Obviously, shortage of essential building bricks will stop the development of copepods, whereas lack of energy may be overcome by reducing metabolic activity, allowing slow but steady growth. Therefore, the ceased development lends further support to the idea that differences in bulk proteins or undetected dif- 
ferences in food concentrations or feeding rates in our experiments do not affect our conclusions on the role of essential lipids. In addition, the requirements for nutrients and energy may change during development, as suggested by the different $\mathrm{P}$ - and $\mathrm{N}$-content of the different life stages of freshwater copepods, possibly linked to the RNA content required for growth (Sterner \& Schulz 1998, Carrillo et al. 2001). The demands for essential lipids among life stages of copepods are probably also not the same. The effects of an unbalanced lipid composition of the diet may, therefore, be specific for somatic growth of nauplius larvae and copepodites, as well as for egg production by adults.

The present study shows the dramatic effect of nitrogen and phosphorus limitation on the composition of essential lipids in the diatom Thalassiosira weissflogii. Although silicate is the nutrient that usually limits the growth of diatoms in the sea, our results may be representative of coastal seas, where diatom growth can be limited by N or P (Fujiki et al. 2004, Lagus et al. 2004). However, considering the important role of PUFAs and sterols in membranes of, among others, chloroplasts and the general relation with algal growth (cf. Introduction), our conclusions may also generally apply to growth limitation of phytoplankton in the sea. Evidence for such a general effect of lipids and their impact further up in the food-chain, is found in the reduced egg production of copepods observed during the course of phytoplankton blooms, which was correlated with a changed fatty acid composition of the seston in coastal as well as in open seas (Jonasdottir et al. 1995, Jonasdottir \& Kiørboe 1996). It seems that the seasonallychanging physical conditions and the associated wax and wane of algal blooms constrain the quality of food available to zooplankton consumers, which will affect the secondary production independent of the phytoplankton biomass. Future studies on food-chain dynamics need to consider the biochemical variability of seston, particularly with regard to the sterol composition, which has largely been neglected in the past.

Acknowledgements. We are grateful to Dr. J. van der Meer and $\mathrm{H}$. Witte for statistical advice, and to Dr. G. J. Herndl for critically reading the manuscript.

\section{LITERATURE CITED}

Anderson TR, Hessen DO (1995) Carbon or nitrogen limitation in marine copepods? J Plankton Res 17:317-331

Anderson TR, Pond DW (2000) Stoichiometric theory extended to micronutrients: comparison of the roles of essential fatty acids, carbon, and nitrogen in the nutrition of marine copepods. Limnol Oceanogr 45:1162-1167

Brett MT, Müller-Navarra DC (1997) The role of highly unsaturated fatty acids in aquatic food web processes. Freshw Biol 38:483-499
Brett MT, Lubnow FS, Villar-Argaiz M, Müller-Solger A, Goldman CR (1999) Nutrient control of bacterioplankton and phytoplankton dynamics. Aquat Ecol 33:135-145

Brown MR, Dunstan GA, Norwood SJ, Miller KA (1996) Effects of harvest stage and light on the biochemical composition of the diatom Thalassiosira pseudonana. J Phycol 32:64-73

Carotenuto Y, Ianora A, Buttino I, Romano G, Miralto A (2002) Is postembryonic development in the copepod Temora stylifera negatively affected by diatom diets? J Exp Mar Biol Ecol 276:49-66

Carrillo P, Villar-Argaiz M, Medina-Sanchez JM (2001) Relationship between N:P ratio and growth rate during the life cycle of calanoid copepods: an in situ measurement. J Plankton Res 23:537-547

Cowles TJ, Olson RJ, Chisholm SW (1988) Food selection by copepods: discrimination on the basis of food quality. Mar Biol 100:41-49

D'Souza FML, Kelly GJ (2000) Effects of a diet of a nitrogenlimited alga (Tetraselmis suecica) on growth, survival and biochemical composition of tiger prawn (Penaeus semisulcatus) larvae. Aquaculture 181:311-329

Enright CT, Newkirk GF, Craigie JS, Castell JD (1986) Growth of juvenile Ostrea edulis L. fed Chaetoceros gracilis Schütt of varied chemical composition. J Exp Mar Biol Ecol 96:15-26

Flynn KJ (1990) Composition of intracellular and extracellular pools of amino acids, and amino acid utilization of microalgae of different sizes. J Exp Mar Biol Ecol 139:151-166

Flynn KJ, Garrido JL, Zapata M, Opik H, Hipkin CR (1992) Changes in fatty acids, amino acids and carbon/nitrogen biomass during nitrogen starvation of ammonium- and nitrate-grown Isochrysis galbana. J Appl Phycol 4:95-104

Fujiki T, Toda T, Kikuchi T, Aono H, Taguchi S (2004) Phosphorus limitation of primary productivity during the spring-summer blooms in Sagami Bay, Japan. Mar Ecol Prog Ser 283:29-38

Goad LJ (1981) Sterol biosynthesis and metabolism in marine invertebrates. Pure Appl Chem 51:837-852

Guillard RRL (1975) Culture of phytoplankton for feeding marine invertebrates. In: Smith WL, Chanley MH (eds) Culture of marine invertebrate animals. Plenum Press, New York, p 29-60

Guisande C, Maneiro I, Riveiro I, Barreiro A, Pazos Y (2002) Estimation of copepod trophic niche in the field using amino acids and marker pigments. Mar Ecol Prog Ser 239: $147-156$

Harrison PJ, Thompson PA, Calderwood GA (1990) Effects of nutrient and light limitation on the biochemical composition of phytoplankton. J Appl Phycol 2:45-56

Hassett RP (2004) Supplementation of a diatom diet with cholesterol can enhance copepod egg-production rates. Limnol Oceanogr 49:488-494

Hazzard SE, Kleppel GS (2003) Egg production of the copepod Acartia tonsa in Florida Bay: role of fatty acids in the nutritional composition of the food environment. Mar Ecol Prog Ser 252:199-206

Jonasdottir SH, Kiørboe T (1996) Copepod recruitment and food composition: Do diatoms affect hatching success? Mar Biol 125:743-750

Jonasdottir SH, Fields D, Pantoja S (1995) Copepod egg production in Long Island Sound, USA, as a function of the chemical composition of seston. Mar Ecol Prog Ser 119: 87-98

Jones RH, Flynn KJ, Anderson TR (2002) Effect of food quality on carbon and nitrogen growth efficiency in the copepod Acartia tonsa. Mar Ecol Prog Ser 235:147-156 
Kiørboe T (1989) Phytoplankton growth rate and nitrogen content: implications for feeding and fecundity in a herbivorous copepod. Mar Ecol Prog Ser 55:2-3

Klein Breteler WCM, Gonzalez SR (1986) Culture and development of Temora longicornis (Copepoda, Calanoida) at different conditions of temperature and food. Syllogeus 58:71-84

Klein Breteler WCM, Gonzalez SR (1988) Influence of temperature and food concentration on body size, weight and lipid content of 2 calanoid copepod species. Hydrobiologia 167/168:201-210

Klein Breteler WCM, Schogt N, van der Meer J (1994) The duration of copepod life stages estimated from stagefrequency data. J Plankton Res 16:1039-1057

Klein Breteler WCM, Gonzalez SR, Schogt N (1995) Development of Pseudocalanus elongatus (Copepoda, Calanoida) cultured at different temperature and food conditions. Mar Ecol Prog Ser 119:99-110

Klein Breteler WCM, Schogt N, Baas M, Schouten S, Kraay GW (1999) Trophic upgrading of food quality by protozoans enhancing copepod growth: role of essential lipids. Mar Biol 135:191-198

Klein Breteler WCM, Koski M, Rampen S (2004) Role of essential lipids in copepod cultivation: no evidence for trophic upgrading of food quality by a marine ciliate. Mar Ecol Prog Ser 274:199-208

Kleppel GS, Burkart CA (1995) Egg production and the nutritional environment of Acartia tonsa: the role of food quality in copepod nutrition. ICES J Mar Sci 52:297-304

Kleppel GS, Hazzard SE (2000) Diet and egg production of the copepod Acartia tonsa in Florida Bay. II. Role of the nutritional environment. Mar Biol 137:111-121

Koski M, Klein Breteler W, Schogt N (1998) Effect of food quality on rate of growth and development of the pelagic copepod Pseudocalanus elongatus (Copepoda, Calanoida). Mar Ecol Prog Ser 170:169-187

Kuijper LDJ, Anderson TR, Kooijman SALM (2004) C and N gross growth efficiencies of copepod egg production studied using a Dynamic Energy Budget model. J Plankton Res 26:213-226

Lagus A, Suomela J, Weithoff G, Heikkila K, Helminen H, Sipura J (2004) Species-specific differences in phytoplankton responses to $\mathrm{N}$ and $\mathrm{P}$ enrichments and the $\mathrm{N}: \mathrm{P}$ ratio in the Archipelago Sea, northern Baltic Sea. J Plankton Res 7:779-798

Leonardos, N, Lucas, IAN (2000) The nutritional value of algae grown under different culture conditions for Mytilus edulis L. larvae. Aquaculture 182:301-315

Miralto A, Barone G, Romano G, Poulet SA and 7 others (1999) The insidious effect of diatoms on copepod reproduction. Nature 402:173-176

Mock T, Kroon BMA (2002) Photosynthetic energy conversion under extreme conditions - I: important role of lipids as structural modulators and energy sink under N-limited growth in Antarctic sea ice diatoms. Phytochemistry 61: $41-51$

Müller-Navarra D (1995) Evidence that a highly unsaturated fatty acid limits Daphnia growth in nature. Arch Hydrobiol 132:297-307

Mullin MM (1963) Some factors affecting the feeding of marine copepods of the genus Calanus. Limnol Oceanogr 8:239-250

Otero A, Garcia D, Morales ED, Aran J, Fabregas J (1997) Manipulation of the biochemical composition of the eicosapentaenoic acid-rich microalga Isochrysis galbana in semicontinuous cultures. Biotechnol Appl Biochem 26: 171-177

Pond D, Harris R, Head R, Harbour D (1996) Environmental and nutritional factors determining seasonal variability in the fecundity and egg viability of Calanus helgolandicus in coastal waters off Plymouth, UK. Mar Ecol Prog Ser 143: $45-63$

Ravet JL, Brett MT, Müller-Navarra DC (2003) A test of the role of polyunsaturated fatty acids in phytoplankton food quality for Daphnia using liposome supplementation. Limnol Oceanogr 48:1938-1947

Reitan KI, Rainuzzo JR, Olsen Y (1994) Effect of nutrient limitation on fatty acid and lipid content of marine microalgae. J Phycol 30:972-979

Reitan KI, Rainuzzo JR, Oie G, Olsen Y (1997) A review of the nutritional effects of algae in marine fish larvae. Aquaculture 155:207-221

Roman MR (1991) Pathways of carbon incorporation in marine copepods: effects of developmental stage and food quantity. Limnol Oceanogr 36:796-807

Rothhaupt KO (1995) Algal nutrient limitation affects rotifer growth rate but not ingestion rate. Limnol Oceanogr 40: 1201-1208

Sargent JR, Parkes RJ, Mueller-Harvey J, Henderson RJ (1987) Lipid biomarkers in marine ecology. In: Sleigh MA (ed) Microbes in the sea. Ellis Horwood, Chichester, p 119-138

Shiffrin NS, Chisholm SW (1981) Phytoplankton lipids: interspecific differences and effects of nitrate, silicate and light-dark cycle. J Phycol 17:374-384

Sterner RW, Schulz KL (1998) Zooplankton nutrition: recent progress and a reality check. Aquat Ecol 32:261-279

Thompson PA, Guo MX, Harrison PJ, Whyte JNC (1992) Effects of variation in temperature. 2. On the fatty acid composition of eight species of marine phytoplankton. J Phycol 28:488-497

van Nieuwerburgh L, Wänstrand I, Snoeijs P (2004) Growth and $\mathrm{C}: \mathrm{N}: \mathrm{P}$ ratios in copepods grazing on $\mathrm{N}$ - or Si-limited phytoplankton blooms. Hydrobiologia 514:57-72

Veron B, Billard C, Dauguet JC, Hartmann MA (1996) Sterol composition of Phaeodactylum tricornutum as influenced by growth temperature and light spectral quality. Lipids 31:989-994

Volkman JK (2003) Sterols in microorganisms. Appl Microbiol Biot 60:495-506

Volkman JK, Hallegraeff GM (1988) Lipids in marine diatoms of the genus Thalassiosira: predominance of 24-methylenecholesterol. Phytochemistry 27:1389-1394

von Elert E (2002) Determination of limiting polyunsaturated fatty acids in Daphnia galeata using a new method to enrich food algae with single fatty acids. Limnol Oceanogr 47:1764-1773

von Elert E, Martin-Creuzburg D, Le Coz JR (2003) Absence of sterols constrains carbon transfer between cyanobacteria and a freshwater herbivore (Daphnia galeata). Proc R Soc Lond B Biol 270:1209-1214

Weers PMM, Gulati RD (1997) Growth and reproduction of Daphnia galeata in response to changes in fatty acids, phosphorus, and nitrogen in Chlamydomonas reinhardtii. Limnol Oceanogr 42:1584-1589

Wood BJB (1988) Lipids of algae and protozoa. In: Ratledge C, Wilkinson SG (eds) Microbial lipids. Academic Press, London, p 806-867

Submitted: May 28, 2004; Accepted: December 16, 2004

Proofs received from author(s): April 3, 2005 